\title{
Identification of feeder service in every station on serving Jenggala Train
}

\author{
Hera Widyastuti ${ }^{1,}$, Dio Hananda Ziantono ${ }^{2}$, Frans de Jesus Babo ${ }^{2}$, Jimi Amijaya ${ }^{2}$, and \\ Rizal Zafikhal Biad Sektyoko ${ }^{2}$ \\ ${ }^{1}$ Civil Engineering, Faculty of Civil Environmental and Geo Engineering, 6011 Surabaya, Indonesia \\ ${ }^{2}$ Civil Engineering, Faculty of Civil Environmental and Geo Engineering, 6011 Surabaya, Indonesia
}

\begin{abstract}
Optimum performance of station affects on the level of service to the consumer that is train service users. The consumers of station or train always want to have appropriate services, from purchasing ticket in ticket counter until waiting for the train to board or arrive. But, based on earlier research, there were still much candidate of passengers looking for information about transportation upon arrival on the station. The purpose of the writing is to evaluate performance and get hints to make some improvements. While, for intermodal analysis of whole railway stations serving KRD Jenggala has been integrated with nearby terminal through the service of feeder that is Lyn.
\end{abstract}

\section{Introduction}

PT. Kereta Api Indonesia is now already operating pioneer trains in several regions in Indonesia [1]. The development of pioneer train is firstly operated on Java Island in East Java regions which are Sidoarjo and Mojokerto. Being named as Kereta Api Perintis Jenggala, this train is operating through Sidoarjo railway station, Tulangan railway station, Tarik railway station, and Mojokerto railway station.

Railway station, also as a transportation node has important role in organizing trains, excellent service is also part of PT. Kereta Api Indonesia (Persero)'s target to maximize the effort in service innovation [2]. With the existence of train that is serving through four railway stations as a node for the writters to do evaluation among stations serving Jenggala train investigating the existing facilities and services as evaluation materials about how far minimum standards in station have been applied and also capable of giving recommendation for better service performance in those railway stations. Surely consumers want to get better services, starting from ordering the tickets until near boarding and also availability of important facilities for the costumers [3].

\footnotetext{
* Corresponding author: hera.widyastuti@yahoo.co.uk
} 


\section{Methodology}

Method that had been done on this preliminary identification was gathering primary data related to observing existing condition on field around the station that became stopping place for KRD Jenggala. That matter is important thing to do for identifying feeder services and connectivity supporting facilities around station that served KRD Jenggala.

\section{Discussions}

\subsection{Intermodal Analysis}

Reviewed from the aspect of population movement, the increase of urban area's residents population and urbanization making the increase of movement to or from the city. This matter gives logic consequence that it is needed for balancing between vehicle and infrastructure especially in transportation. This is meant to support the mobility of the population to do their activities. One of the method to fulfill the needs of transportation service is by providing public transportation $[4,5]$.

KRD Jenggala is one of the rail based mass transportation that is offered by PT. KAI to support the movement of people from Sidoarjo to Mojokerto or vice versa. This train is inaugurated in November $12^{\text {th }} 2014$ to serve pioneer route in line between Sidoarjo Railway Station until Tarik Railway Station and continues until Mojokerto Railway Station. KRD Jenggala consists of two chained new AC built train made by PT. Industri Kereta Api (INKA) Madiun, which each has four diesel train units of economic class with AC built.

Availability of feeder service and supportive facility in nearby stations become the place for KRD Jenggala to stop is important component that must be noticed to ease the event of transportation movement for KRD Jenggala service users from one place to another. This matter is important to do to attract people's interest to use JRD Jenggala as primary transportation option in their daily. The availability of vehicle and infrastructure connectivity services on every station that become a place for KRD Jenggala to stop, the performance needs to be improved. Cross of train services need internal alignment and between modal transportation, distance of the hub, and central logistic toward the terminal/station and time availability for internal movement and between modal transportation. (PP 72/09) [6]. Therefore a first identification related to the connectivity on every station that becomes the place for KRD Jenggala to stop is needed. The purpose for first identification to be done is that to identify if there are feeder services and supportive facilities around the stations that become the place KRD Jenggala to stop.

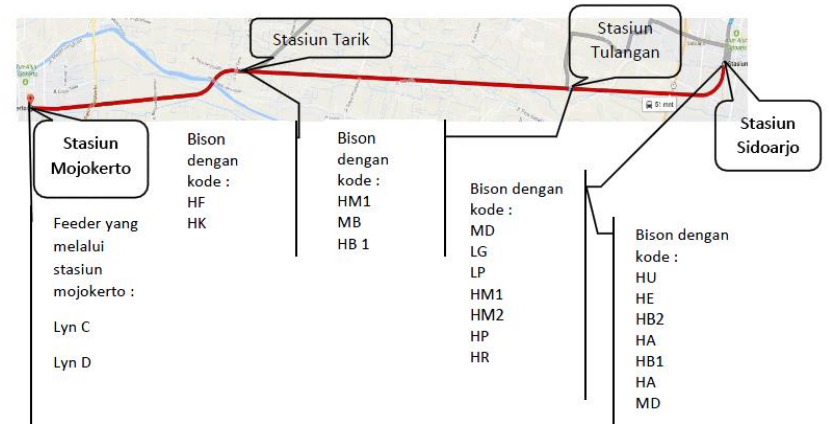

Fig. 1. Station's Feeder Network Map 
Table 1. Amount of Feeder Services on Every Station.

\begin{tabular}{|l|c|c|l|c|}
\hline \multicolumn{1}{|c|}{ Station Name } & Station Class & Terminal Availability & \multicolumn{1}{|c|}{ Feeder Services } & Feeder Total \\
\hline Sidoarjo Station & Big & Yes & $\begin{array}{l}\text { HU, HE, HB2, HB1, } \\
\text { HA, MD, LG, LP, } \\
\text { HM1, HM2, HP, HR }\end{array}$ & 12 \\
\hline Tulangan Station & Small & Yes & HM1, MB & 2 \\
\hline Tarik Station & Small & Yes & HF, HK & 2 \\
\hline Mojokerto Station & Big & Yes & Lyn C and Lyn D & 2 \\
\hline
\end{tabular}

Table 2. Feeder Services Crossing on Sidoarjo Station.

\begin{tabular}{|c|c|c|}
\hline No & $\begin{array}{c}\text { Type of Feeder } \\
\text { Services }\end{array}$ & Feeder Services Routes \\
\hline \multicolumn{3}{|c|}{ Sidoarjo Station } \\
\hline 1 & Lyn HA & $\begin{array}{l}\text { Terminal Larangan }- \text { Jl. Diponegoro - Raya Jati - Cemengkalan - Embong } \\
\text { Malang - Sumput }- \text { Sarirogo - Raya Wulung - Raya Saimbang - Kebonagung - } \\
\text { Patimura - Panjuran - Sandang pangan - Jemundo - Sawunggaling - Raya Kltek - } \\
\text { Raya Geluran - Raya Kalijaten - Ps Taman - PP }\end{array}$ \\
\hline 2 & Lyn HB 1 & $\begin{array}{l}\text { Terminal Larangan - Jl.Diponegoro - Jl.Pahlawan - Raya Jati - Raya Cemengkalan - } \\
\text { Ray Suko - Raya Lebo - Raya Pangliam Sudirman - Raya Pilang - Raya Banar - } \\
\text { Raya Modong - Raya Kemantren - Raya Tulangan - Raya Kepadangan - Raya } \\
\text { Kebaron - Raya Wonomlati - Raya Krembung - PP. }\end{array}$ \\
\hline 3 & Lyn HB 2 & $\begin{array}{l}\text { Terminal Larangan - Jl.Diponegoro - Jl.Pahlawan - Raya Jati - Raya Cemengkalan } \\
\text { - Raya Suko- Raya Lebo - Raya Panglima Sudirman - Raya Pilang - Raya Ketimang } \\
\text { Raya Jimbaran - Raya Wonoayu - Raya Semambung - Raya Simo Angin-angin - } \\
\text { Raya Tanggul - Ds. Tropodo Raya Prambon - Raya Terminal Krian- PP. }\end{array}$ \\
\hline 4 & Lyn HE & $\begin{array}{l}\text { Pasar Porong - Ray Bhayangkari - Jl.Diponegoro - Ds. Lajuk - Jololeksono- Jenggot - } \\
\text { Ploso - Rejeni - Raya Kandangan - Raya Krembung - Lemujut - Cangkring - } \\
\text { Bulang - Simpang - Pejangkungan - Kates - Wirobitung - Jl. Brawijaya - } \\
\text { Gedangrowo - Jl.Mojopahit - Prambon-PP. }\end{array}$ \\
\hline 5 & Lyn HM 1 & $\begin{array}{l}\text { Terminal Larangan - Jl. Diponegoro - Jl. Tthamrin - Jl. Gajahmada - Jl. Mojopahit - } \\
\text { Jl. Bligo - Raya Candi - Raya Gelam - Sumorame - Karangtanjung - Kedondong } \\
\text { - Sidomoro - Medalem - Pasar Tulangan - PP. }\end{array}$ \\
\hline 6 & Lyn HM 2 & $\begin{array}{l}\text { Terminal Larangan - J1 Diponegoro - J1. Thamrin - Jl. Gajah Mada - Jl. Mojopahit - } \\
\text { Jl. Bligo - Raya candi Raya Gelam - Sumorame - Karangtanjung - Gagangpanjang - } \\
\text { Randegan - Kategan - Kendensari - Kalisampurno - Ketapang - Pasar Porong - PP. }\end{array}$ \\
\hline 7 & Lyn HP & $\begin{array}{l}\text { Terminal Larangan - Jl. Diponegoro - Jl. Thamrin - Jl. Kombers Duriat - Jl. Kartini - Jl. } \\
\text { Yos Sudarso - Bluru Kidul - Kemiri - Siwalan Panji - Sidomulyo - Prasung - } \\
\text { Dukuhtengah - Damarsih - Sawoan - Kwangsan -Betro - Sedatiagung - PP. }\end{array}$ \\
\hline 8 & Lyn HR & $\begin{array}{l}\text { Terminal Larangan - Jl. Diponegoro - Jl. Pahlawan - Raya Jati - Cemengkalang - } \\
\text { Cemengbakalan - Urangagung - Mojorangagung - Wonokasihan - Sawocangkring } \\
\text { - Lambangan - Kemulan - Becirongengor - PP. }\end{array}$ \\
\hline 9 & Lyn HU & $\begin{array}{l}\text { Terminal Larangan - Jl. Diponegoro - Jl. Pahlawan - Jl. Teuku Umar - Jl. Sultan } \\
\text { Agung - Jl. Pagerwojo - Entalsewu - Sidokepung - Jumputrejo- Ganting - } \\
\text { Masangan Wetan - Bohar - Wage - Pepelegi - Medaeng - Raya Geluran - Raya } \\
\text { Kalijaten - Pasar Taman - PP. }\end{array}$ \\
\hline 10 & Lyn LP & $\begin{array}{l}\text { Terminal Larangan - Jl. Diponegoro - Jl. Thamrin - Jl. A.Yani - Jl. Jenggolo - } \\
\text { Raya Buduran - Tebel - Kranggan - Gemurung -Kwangsan - Pepe - Pulungan - }\end{array}$ \\
\hline 11 & Lyn LG & $\begin{array}{l}\text { Terminal Larangan - Jl. Diponegoro - Jl. Thamrin - Jl. A. Yani - Jl. Jenggolo - Jl. } \\
\text { Yos Sudarso - Jl. R.A Kartini - Jl. Trunojoyo - Bluru Kidul - rangkah Kidul - } \\
\text { Perum .Intan Permai - Gebang - PP. }\end{array}$ \\
\hline 12 & Lyn MD & $\begin{array}{l}\text { Terminal Larangan - Jl. Diponegoro - Jl. Thamrin - Jl. Gajah Mada - Jl. Mojopahit - } \\
\text { Raya Bligo - Raya Candi - Ds. Gelam - Sugihwaras - Kedung Kendo - Durung } \\
\text { Banjar - Durung Bedug - Modong - Kepuh Kemiri - Grabagan - Popoh - Simo } \\
\text { Ketawang - Simo Girang - Watutulis - PP. }\end{array}$ \\
\hline
\end{tabular}


Table 3. Feeder Services Crossing on Tulangan, Tarik and Sidoarjo Station.

\begin{tabular}{|c|c|c|}
\hline No & $\begin{array}{l}\text { Type of Feeder } \\
\text { Services }\end{array}$ & Feeder Services Routes \\
\hline \multicolumn{3}{|c|}{ Tulangan Station } \\
\hline 1 & Lyn HM 1 & $\begin{array}{l}\text { Terminal Larangan - Jl. Diponegoro - Jl. Tthamrin -Jl. Gajahmada - Jl. Mojopahit } \\
\text { - Jl. Bligo - Raya Candi Kedondong - Sidomoro - Medalem - Pasar Tulangan - PP - } \\
\text { Raya Gelam - Sumorame - Karangtanjung - PP. }\end{array}$ \\
\hline 2 & Lyn MB & $\begin{array}{l}\text { Terminal Krian - Sidomulyo - Jeruklegi - Penambangan - Bogempinggir - Pasar } \\
\text { Tulangan - PP. }\end{array}$ \\
\hline \multicolumn{3}{|c|}{ Tarik Station } \\
\hline 1 & Lyn HF & $\begin{array}{l}\text { Terminal Krian - Raya Kemangsen - Balongbendo - Bakalan - Waruberon - Jati } \\
\text { Kemuning - Balongmace'an - Tarik- PP. }\end{array}$ \\
\hline 2 & Lyn HK & $\begin{array}{l}\text { Terminal Krian - Tropodo - Klagen - Kedungwonokerto }- \text { Klantingsari - } \\
\text { Mergosari }- \text { Tarik }- \text { Singogalih }- \text { Kedungbocok - Miripprowo }- \text { PP. }\end{array}$ \\
\hline \multicolumn{3}{|c|}{ Sidoarjo Station } \\
\hline 1 & Lyn C & $\begin{array}{l}\text { Terminal Kertajaya - Jl. Jaya Negara - Mangelo - Jl. Jaya Wardana (Jl. Wijaya } \\
\text { Kusuma) - Jl. RA. Basuni - Jl. Sooko - Brangkal - Jl. Sooko - Jl. RA. Basuni - Jl. } \\
\text { Mojopahit - Jl. Bhayangkara - Jl. KH. Nawawi - Jl. Cokroaminoto - J1. Gajah } \\
\text { Mada - Jl. Pahlawan - Jl. Jaya Negara - Terminal Kertajaya. }\end{array}$ \\
\hline 2 & Lyn D & $\begin{array}{l}\text { Terminal Kertajaya - Jl. Meri - J1. Tropodo - Jl. Pahlawan - Jl. Gajah Mada - Jl. } \\
\text { Cokroaminoto - Jl. KH. Nawawi - Jl. Bhayangkara - Jl. Mojopahit - Jl. Tribuana } \\
\text { Tungga Dewi - Jl. Surodinawan - J1. Sambiroto - Brangkal - Jl. Sambiroto - Jl. KH. } \\
\text { Usman - Jl. Jaya Wardhana - Jl. Teratai - J1. R. Wijaya - Jl. Jaya Negara - Terminal } \\
\text { Kertajaya. }\end{array}$ \\
\hline
\end{tabular}

On the table 1, based on identification it can be inferred that Sidoarjo Station is the most station that the feeder services are going through which is 12 Lyns. The feeder services in their operation have different routes. Route tracks of each Lyn shows in the table 2 and 3.

\section{Conclusions}

Result of first identification that is obtained from the survey that all stations serving KRD Jenggala have operational feeders from station to nearby terminal. But the availability of this feeder is not supported with supportive facility like schedule of feeder's arrival or information board about feeder service routes that are operational in station to connect to the terminals. And to improve the performance of future services, the writers is giving advice so that there will be regulation to organize connectivity between main mode and feeder to be one company that provides transportation service. Because as for now between the owner of main mode and owner of feeder are from different companies so it is difficult to synchronize the importance between both companies without having regulation that specially organizes the connectivity between both of them.

\section{References}

1. Honing, J. Ilmu Bangunan Jalan Kereta Api. Jakarta: PT.Pradya Pramita. (1975).

2. Martila A. John and James C. John. The Analysis of the Importance and Satisfaction level of the Customers. New Jersey:Prentice Hall Inc. (1997).

3. Kotler, Philip. Marketing Management. New Jersey: Prentice Hall Inc. (2000).

4. Umar, H. Metode Riset Perilaku Konsumen Jasa. Jakarta: Ghalia Indonesia. (2003).

5. Tjiptono, J. and Chandra, G. Service, Quality Satisfaction. Yogyakarta: Andi. (2005).

6. Department of Transportation of Indonesia, Regulation of the Minister No. 9 of 2011 for Standard Minimum Service of Public Transport using Train. Jakarta (2011). 